\title{
Genetic Diversity among Tomato Accessions based on Agro-Morphological Traits
}

\author{
(Kepelbagaian Genetik antara Penerimaan Tomato berdasarkan Ciri Agro Morfologi)
}

IZHAR Hussain*, Sher Aslam Khan, SAJid Ali, Abid FArid, NAUShad Ali, SARdar Ali, SHAH MASAUD, IJAZ HUSSAIN, KAMRAN AZEEM \& HANEEF RAZA

\begin{abstract}
It is of great importance to know about the genetic diversity, conservation and classification for further utilization of tomato germplasm resources. Therefore, 40 tomato accessions were evaluated on the basic of agro-morphological traits for genetic diversity in 2014. The experiment was conducted at Agricultural Research Farm, University of Haripur and farmer field in Swabi, Khyber Pakhtunkhwa, Pakistan. Principal component analysis showed that five out of 27 principal components with an eigenvalue above 1.0 were considered for $74.10 \%$ of the total variance. The major contributing traits in variations were days to flowering (DFL), days to fruiting (DFR), fruit size (FS), fruit weight plant ${ }^{-1}(F W)$, yield plot ${ }^{-1}$ (YPP), yield hectare $^{-1}(Y P H)$, leaf length (LL), predominant fruit shape (PDFS), fruit length (FL), fruit width (FWidth), clusters plant $^{-1}(C P P)$, fruits plant ${ }^{-1}(F P P)$ and plant height $(P H)$. The scattered plot of the PC's revealed that the accessions were scattered in all the quarters, which is also a representative that high level of genetic variability was present. $F W$ and $F L$ were positively correlated with YPH. However, the remaining yield components indirectly contributed YPH.Cluster analysis divided 40 accessions into four main clusters (I, II, III and IV), each of which having 12, 11, 07 and 10 accessions. The accessions in clusters I and II were statistically similar and performed better in terms of yield and yield related traits. Grouping into different clusters was associated with their agro-morphological differences. These results could be serving as a useful resource for further characterization, preservation and breeding programs.
\end{abstract}

Keywords: Accessions; analysis; cluster; diversity; tomato

\section{ABSTRAK}

Adalah penting untuk mengetahui tentang kepelbagaian genetik, pemuliharaan dan pengelasan bagi penggunaan sumber germplasma tomato. Oleh itu, 40 penerimaan tomato telah dinilai berasaskan ciri agro morfologi bagi kepelbagaian genetik pada tahun 2014. Uji kaji ini telah dijalankan di Ladang Penyelidikan Pertanian, Universiti Haripur dan padang petani di Swabi, Khyber Pakhtunkhwa, Pakistan. Analisis komponen utama menunjukkan bahawa lima daripada 27 komponen utama dengan nilai eigen melebihi 1.0 telah diambil kira $74.10 \%$ daripada jumlah varians. Ciri utama penyumbang dalam variasi ialah hari untuk berbunga (DFL), hari untuk berbuah (DFR), saiz buah (FS), berat pokok buahbuahan $^{-1}(F W)$ hasil plot ${ }^{-1}(Y P P)$, hasil hektar-1 (YPH), panjang daun (LL), bentuk utama buah-buahan (PDF), panjang buah

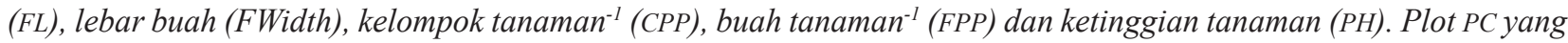
berselerak menunjukkan penerimaan adalah berselerak di dalam semua bahagian yang mewakili kepelbagaian genetik tahap tinggi telah berlaku. FW dan FL berkorelasi secara positif dengan YPH. Walau bagaimanapun, komponen hasil baki secara tidak langsung menyumbang kepada YPH. Analisis kelompok membahagikan 40 penerimaan kepada empat kelompok utama (I, II, III dan IV) dengan setiap daripadanya mempunyai 12, 11, 07 dan 10 penerimaan. Penerimaan untuk kelompok I dan II adalah sama secara statistik dan menunjukkan hasil yang lebih baik dari sudut penghasilan dan ciri berdasarkan penghasilan. Pengelompokan kepada kelompok yang berlainan dikaitkan dengan perbezaan agro morfologi mereka. Keputusan kajian ini sangat membantu sebagai satu sumber yang berguna untuk kesinambungan pencirian, pemeliharaan dan program pembiakbakaan.

Kata kunci: Analisis; kluster; kepelbagaian; penerimaan; tomato

\section{INTRODUCTION}

Tomato (Lycopersicon esculentum Mill., $2 \mathrm{n}=2 \mathrm{x}=24$ ) is one of the most important Solanaceous vegetable crops grown in every corner of the world. It is flexible in nature and used in various cooked and processed forms as well as fresh form as a salad. It can be processed into puree, paste, ketchup, sauce and soup. During 2013-2014, tomato was harvested from an area of 4.73 million ha with a production of 163.964 million tonnes worldwide (FAOSTAT 2015). Total production of tomato in Pakistan was 570.6 thousand tonnes, whereas area under cultivation of tomato was 60.7 thousand ha. The average yield per ha in Pakistan is 9.4 tonnes whereas in Khyber Pakhtunkhwa is 9.9 tonnes, which is much lower than the world average i.e. 36 tonnes per ha (MNFSR 2014-15). Besides yield limiting factors, the less availability of information on genetic diversity and 
adaptability misguides the choice of parents suitable for hybridization program. Consequently, the hybrids $\left(\mathrm{F}_{1} \mathrm{~s}\right)$ or recombinants (selected at $\mathrm{F}_{1}$ or later generations) very often do not express full spectrum of genetic trait (s) of interest owing to limited genetic base and inappropriate selection of the parents. This problem can only be overcome if the breeders have substantial information on genetic diversity of source population.

It is of great importance to have a clear understanding of the genetic diversity and relationship between cultivated tomatoes and their wild species for effective conservation, classification, and further utilization of tomato germplasm resources (Zhou et al. 2015). Unfortunately, the lack of information on the origin, diversity and relationship of landraces, along with the phenotyping costs for specific traits, represent the main limiting factors for their use in breeding programs, although it is well known that cultivated germplasm resources provide an important genetic basis for both breeding and genetic research (Flint-Garcia et al. 2005; Huang et al. 2012; Thornsberry et al. 2001). The management, maintenance and characterization of all accessions of a collection is economically demanding. Such study focuses on the degree of similarities or dissimilarity in genetic resources leading to set up organization of gene banks and isolation of best parental combinations (Rashid et al. 2008; Reif et al. 2005; Yi et al. 2008). Following hybridization, these parental combinations can possibly produce progenies with elevated genetic variability, thereby increases chances of creating superior genotypes with traits of interest (Crossa \& Franco 2004; Mohammadi \& Prasanna 2003).

Morphological description and classification is a traditional approach to quantify genetic differences, and is often used for genetic diversity analysis (Khadivi-khub et al. 2008; Nikoumanesh et al. 2011; Terzopoulos \& Bebeli 2008;). In tomato, yield is the cumulative effect of many components contributing individually to yield (Bernousi et al. 2011). Different characteristics viz. number of flowers cluster $^{-1}$, days to first fruit ripening, fruit weight, fruit length and fruit width assume vital importance and must be assessed for genetic divergence aiming to develop high yielding tomato varieties or hybrids. The most commonly used algorithms for this purpose are canonical variable analysis, principal component analysis and clustering methods (Mohammadi \& Prasanna 2003; Sudre et al. 2007). Principal component analysis is frequently used to determine the relative significance of different variables of classification prior to cluster analysis (Jackson 1991). Additionally, principal component analysis also gives a reduced dimension model that would point out the measured differences among different groups and lead to understanding of variables by telling how much of the total variance explained by each one. Statistics is a powerful tool for measuring divergence among a set of population on the basis of statistical distance utilizing multivariate measurements.

The present study was conducted to categorize the available germplasm into separate clusters or groups on the basis of genetic diversity among their morphological attributes using agglomerative hierarchical clustering and principal component analysis. Having performed analysis, the desirable groups of genotypes could be crossed with confidence to develop either open pollinated or hybrid varieties on commercial scale.

\section{MATERIALS AND METHODS}

The experimental materials comprising 40 tomato accessions of diverse origin were acquired from National Agriculture Research Center (NARC), Islamabad and Federal Seed Certification and Registration Department (FSC\&RD), Islamabad, Pakistan in January 2014 (Table 1). Experimental design was Randomized Complete Block Design (RCBD) with three replications at two different locations of Khyber Pukhtunkhwa i.e. Agriculture Research Farm, University of Haripur, Haripur (lat. 33.9781 ${ }^{\circ} \mathrm{N}$, long. $72.9128^{\circ}$ E, elevation $520 \mathrm{~m}$ ) and farmer field in Swabi (lat. 34 $11^{\prime} 22$ "N, long. 72 $22^{\prime} 31^{\prime \prime}$ E, elevation $365.5 \mathrm{~m}$ ). The planting was conducted in summer 2014 . The plot size was $7.68 \mathrm{~m}^{2}$ having row to row distance of $120 \mathrm{~cm}$ and plant to plant distance of $40 \mathrm{~cm}$. The crop was raised at optimum growing conditions. The experiment was maintained according to the recommended cultural practices (Hanson et al. 2000).

Data were recorded for number of day to germination (DTG), number of day to $50 \%$ flowering (DFL), corolla color (CC), number of day to fruiting (DFR), number of flowers cluster/truss ${ }^{-1}$ (FPC), number of fruits cluster ${ }^{-1}$ (FRPC), number of clusters plant ${ }^{-1}(\mathrm{CPP})$, number of fruit plant $\mathrm{t}^{-1}$ (FPP), yield plot $^{-1}$ (YPP), plant height (PH), leaf length (LL), leaf width (LW), fruit length (FL), fruit width (FWidth), number of locules fruit ${ }^{-1}$ (LPF), predominant fruit shape (PDFS), fruit shoulder shape (FSS), fruit color pre-maturity (FCPM), fruit color at maturity (FCM), mature fruit interior flesh color (MFIFC), fruit diameter (FD), fruit size (FS), plant stem girth (PSG), plant stem diameter (PSD), fruit weight plant ${ }^{-1}$ (FW), yield hectare ${ }^{-1}(\mathrm{YPH})$ and plant growth type (PGT).

\section{STATISTICAL ANALYSIS}

All the recorded data were averaged and the means of all the accessions were analyzed for simple statistics (mean, standard deviation, coefficient of variation and variance). Simple correlation coefficient was calculated through the procedure of Steel and Torrie (1980) by means of plot mean values using software Statistica 7.0. The agromorphological traits recorded during the present study were also analyzed by arithmetical taxonomic techniques through multivariate analysis including cluster and principle component analysis (PCA) (Sneath \& Sokal 1973). Means of all the traits were standardized through Z-scores to avoid the effects of scaling differences before the multivariate analysis. Euclidean distances coefficient was determined for the total pairs of genotypes. Resultant Euclidean distances coefficient matrices were used to assess the association among the tomato accessions through 
TABLE 1. List of tomato accessions evaluated for genetic diversity based on agro- morphological traits

\begin{tabular}{cclcll}
\hline S. No. & Accession No. & \multicolumn{1}{c}{ Source } & S. No. & Accession No. & \multicolumn{1}{c}{ Source } \\
\hline 1 & Acc-06232 & *NARC (Pakistan) & 21 & AVR-211 & **AVRDC (Taiwan) \\
2 & Acc-10572 & NARC (Pakistan) & 22 & CLN-222 & USA \\
3 & Acc-10587 & NARC (Pakistan) & 23 & CLN-232 & USA \\
4 & Acc-17867 & NARC (Pakistan) & 24 & AVR-241 & AVRDC (Taiwan) \\
5 & Acc-17870 & NARC (Pakistan) & 25 & AVR-251 & AVRDC (Taiwan) \\
6 & Acc-17872 & NARC (Pakistan) & 26 & AVR-261 & AVRDC (Taiwan) \\
7 & Acc-17874 & NARC (Pakistan) & 27 & CLN-272 & USA \\
8 & Acc-17877 & NARC (Pakistan) & 28 & CLN-282 & USA \\
9 & Acc-17878 & NARC (Pakistan) & 29 & CLN-292 & USA \\
10 & Acc-17879 & NARC (Pakistan) & 30 & EUR-303 & Holand \\
11 & Acc-17882 & NARC (Pakistan) & 31 & CLN-312 & USA \\
12 & Acc-17883 & NARC (Pakistan) & 32 & AVR-321 & AVRDC (Taiwan) \\
13 & Acc-17889 & NARC (Pakistan) & 33 & EUR-333 & Holland \\
14 & Acc-17890 & NARC (Pakistan) & 34 & AVR-341 & AVRDC (Taiwan) \\
15 & Acc-19288 & NARC (Pakistan) & 35 & CLN-352 & USA \\
16 & Acc-19289 & NARC (Pakistan) & 36 & CLN-362 & USA \\
17 & Acc-19290 & NARC (Pakistan) & 37 & STM- 1 & Local collection (Swabi, Pakistan) \\
18 & Acc-19893 & NARC (Pakistan) & 38 & STM- 2 & Local collection (Swabi, Pakistan) \\
19 & Acc-19912 & NARC (Pakistan) & 39 & STM-3 & Local collection (Swabi, Pakistan) \\
20 & AVR-201 & AVRDC (Taiwan) & 40 & Sahel & Syngenta \\
\hline
\end{tabular}

*NARC $=$ National Agriculture Research Center

**AVRDC $=$ Asian Vegetable Research and Development Center

cluster analysis (NTSYS-pc, version 2.1). Furthermore, PCA was performed through similar data matrix.

\section{RESULTS}

\section{PCA BASED ON AGRO-MORPHOLOGICAL TRAITS}

PCAwas carried out based on 27 quantitative traits. It was found that five out of 27 principal component with an eigenvalue above 1.0 contributed for $74.10 \%$ of the total variations. The coefficients defining five principal components of the present data are given in Table 2 . The coefficients are given for the purpose because these might show the correlations between observed and derived variables.

PC1 contributed $37.12 \%$ to the total variance $(74.10 \%)$. The traits which contributed positively to the PC1 were DTG (0.168), DFL (0.118), DFR (0.131), FW (0.115), FD (0.268), FWidth (0.270), FL (0.249), PSG (0.162), PSD (0.161),

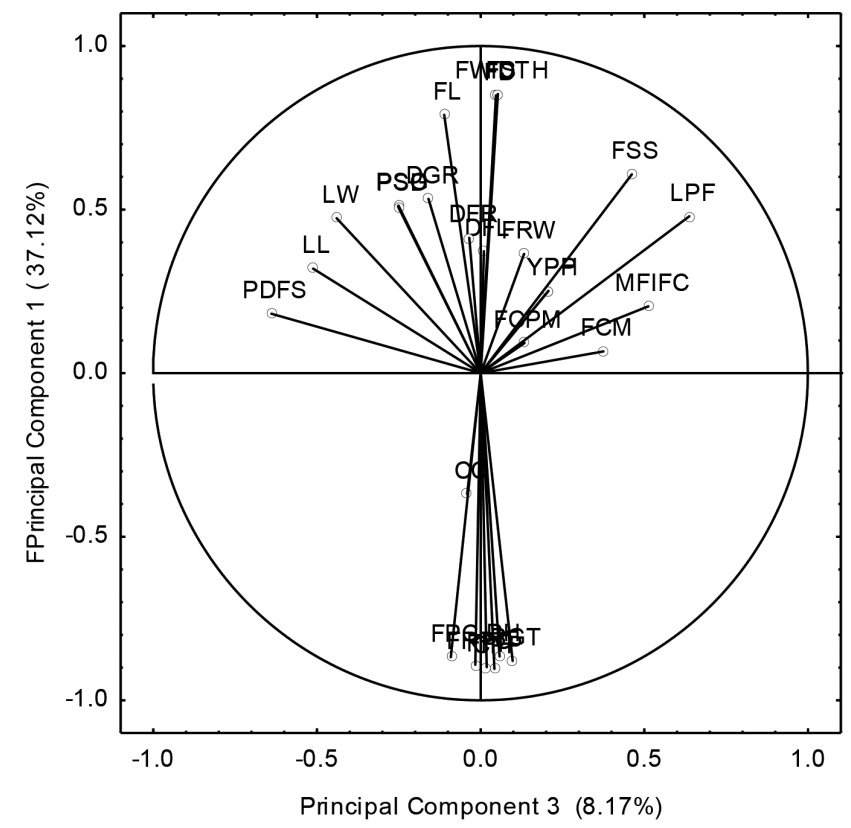

FIGURE 1. Scatter plot depict the contribution of agro-morphological in the first and third principal components in 40 tomato accessions 


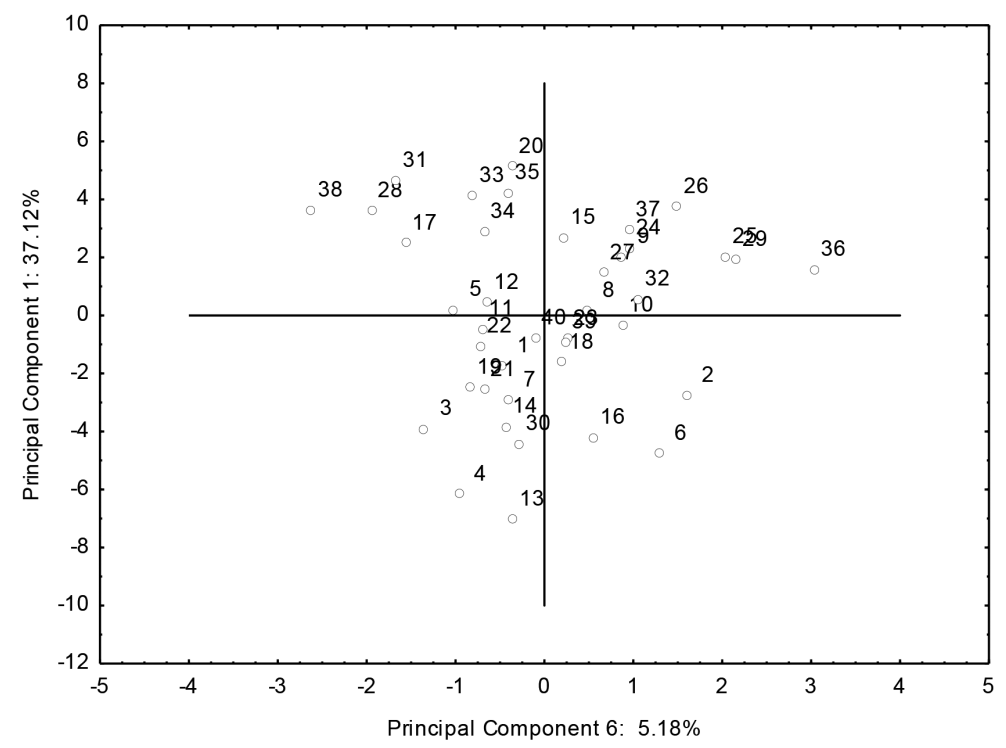

FIGURE 2. Scatter plot showing the genetic relationships among 40 tomato accessions as showed by first and sixth principal components

LL (0.101), LW (0.150), FSS (0.192), LPF (0.151) and FS (0.270). The contributions of YPP (0.079), YPH $(0.080)$, FCPM (0.029), FCM (0.021), PDFS (0.057) and MFIFC (0.065) were also found to have positive weight on PC1 but their weight was less in magnitude.

Similarly, PC2 contributed $15.79 \%$ to the total variation, in which the traits CPP (0.105), FPP (0.116), FW (0.390), YPP (0.407), YPH (0.407), PH (0.112), PSG (0.260), PSD (0.260), LL (0.240), LW (0.104), CC (0.113), FCPM $(0.123)$, FCM $(0.135)$ and MFIFC $(0.192)$ were positively contributed to PC2. The contributions of FPC (0.075), FRPC (0.069), FL (0.099), PDFS (0.059) and PT (0.091) were also observed to have positive weight on PC 2 but comparatively very less in amount.

The share of PC3 in total variance was $8.17 \%$ in which the major contributors were YPP (0.140), YPH (0.139), FCM (0.252), FSS (0.311), MFIFC (0.345) and LPF (0.429). DFL (0.007), CPP (0.028), FPP (0.013), FW (0.089), FD (0.031), FWidth (0.035), PH (0.039), FCPM (0.090), PGT (0.066) and FS (0.035) also contributed positively but their shared magnitude was very low.

Similarly, the contribution of PC4 in the total variation was $9.94 \%$. The traits which positively contributed to the PC4 were plant cluster (0.169), FPC (0.145), FPP (0.187), FD (0.313), FWidth (0.308), FL (0.248), PH (0.223), LL (0.250), LW (0.108), CC (0.148), FCM (0.101), FSS (0.178), MFIFC (0.131), LPF (0.103), PGT (0.137), FS (0.308). DGR (0.024) and FRPC $(0.097)$ were also observed to have positive contribution in PC4 but their weights were comparatively less in magnitude.

The total variation contributed by PC5 was $6.07 \%$. The positive contributors among the studied traits in PC5 were DGR (0.273), CPP (0.106), FPC (0.114), FRPC (0.125), FPP (0.101), PH (0.133), PSG (0.275), PSD (0.278), FCPM $(0.216)$, FSS (0.153) and LPF (0.113). FD (0.053), F Width (0.058), LW (0.048), plant growth type (0.035) and fruit size
(0.058) also contributed positively to the PC5 but in very less amount. Neither of the traits were found common in PC1, PC2, PC3, PC4 and PC5.

\section{CLUSTER ANALYSIS THROUGH AGRO-MORPHOLOGICAL TRAITS}

Dendrogram formed through cluster analysis based on 27 agro-morphological traits divided the 40 tomato accessions into four main clusters (I, II, III \& IV) (Table 2; Figure $3)$. Each cluster was further divided into two sub-clusters. Cluster I consisted of 12 accessions and was further divided into two sub-clusters i.e. IA and IB. Sub-cluster IA consisted of five accessions while IB consisted of seven accessions. Similarly, cluster II comprised of 11 accessions. Cluster II was further divided into two sub-groups i.e. IIA and IIB. Sub-group IIA comprising of six accessions while sub-group IIB consisted of five accessions. Cluster III was the smallest among all the clusters consisting seven accessions. It was further classified into two sub-clusters i.e. IIIA and IIIB consisting four and three accessions respectively. Furthermore, cluster IV consisted of 10 accessions. It was also divided into two sub-clusters. Out of these 10 accessions, three were included in sub-cluster IVA while seven were included in sub-cluster IVB. The means and standard deviations of the four clusters are given in Table 4.

In the present investigation it was observed through cluster analysis that the 40 tomato accessions were divided clearly into its particular groups. Through the calculated data the intra specific differences among the accessions were observed. For these accessions common statistics which included mean and standard deviation were calculated (Table 4). Some significant features were observed for accessions grouped in four clusters (Table 5). 
TABLE 2. Principal components of agro-morphological traits in tomato

\begin{tabular}{|c|c|c|c|c|c|}
\hline & PC1 & PC2 & PC3 & PC4 & PC5 \\
\hline Eigenvalue & 10.02 & 4.26 & 2.21 & 1.87 & 1.64 \\
\hline Cumulative eigenvalue & 10.02 & 14.29 & 16.49 & 18.37 & 20.01 \\
\hline$\%$ Total variance & 37.12 & 15.79 & 8.17 & 6.94 & 6.07 \\
\hline Cumulative \% & 37.12 & 52.91 & 61.08 & 68.03 & 74.10 \\
\hline Traits & \multicolumn{5}{|c|}{ Eigen Vectors } \\
\hline Days to germination (\#) & 0.168 & -0.039 & -0.107 & 0.024 & 0.273 \\
\hline Days to flowering (\#) & 0.118 & -0.283 & 0.007 & -0.202 & -0.084 \\
\hline Days to fruiting (\#) & 0.131 & -0.269 & -0.023 & -0.193 & -0.071 \\
\hline Cluster per plant (\#) & -0.285 & 0.105 & 0.028 & 0.169 & 0.106 \\
\hline Flower per cluster (\#) & -0.274 & 0.075 & -0.061 & 0.145 & 0.114 \\
\hline Fruit per cluster (\#) & -0.282 & 0.069 & -0.011 & 0.097 & 0.125 \\
\hline Fruit per plant (\#) & -0.284 & 0.116 & 0.013 & 0.187 & 0.101 \\
\hline Fruit weight per plant $(\mathrm{kg})$ & 0.115 & 0.390 & 0.089 & -0.214 & -0.051 \\
\hline Yield per plot (kg) & 0.079 & 0.407 & 0.140 & -0.215 & -0.027 \\
\hline Yield per hectare (tonnes) & 0.080 & 0.407 & 0.139 & -0.215 & -0.028 \\
\hline Fruit diameter $(\mathrm{cm})$ & 0.268 & -0.018 & 0.031 & 0.313 & 0.053 \\
\hline Fruit width $(\mathrm{cm})$ & 0.270 & -0.017 & 0.035 & 0.308 & 0.058 \\
\hline Fruit length $(\mathrm{cm})$ & 0.249 & 0.099 & -0.075 & 0.248 & -0.118 \\
\hline Plant height $(\mathrm{cm})$ & -0.274 & 0.112 & 0.039 & 0.223 & 0.133 \\
\hline Plant stem girth $(\mathrm{cm})$ & 0.162 & 0.260 & -0.169 & -0.041 & 0.275 \\
\hline Plant stem diameter $(\mathrm{cm})$ & 0.161 & 0.260 & -0.170 & -0.042 & 0.278 \\
\hline Leaf length $(\mathrm{cm})$ & 0.101 & 0.240 & -0.344 & 0.250 & -0.050 \\
\hline Leaf width $(\mathrm{cm})$ & 0.150 & 0.104 & -0.296 & 0.108 & 0.048 \\
\hline Corolla color (IPGRI scale) & -0.117 & 0.113 & -0.028 & -0.318 & -0.427 \\
\hline Fruit color pre maturity (IPGRI scale) & 0.029 & 0.123 & 0.090 & -0.318 & 0.216 \\
\hline Fruit color at maturity (IPGRI scale) & 0.021 & 0.135 & 0.252 & 0.101 & -0.248 \\
\hline Predominant fruit shape (IPGRI scale) & 0.057 & 0.059 & -0.430 & -0.039 & -0.424 \\
\hline Fruit shoulder shape (IPGRI scale) & 0.192 & -0.070 & 0.311 & -0.039 & 0.153 \\
\hline Mature fruit interior flesh color (IPGRI scale) & 0.065 & 0.192 & 0.345 & 0.131 & -0.391 \\
\hline Locules per fruit (\#) & 0.151 & -0.038 & 0.429 & 0.103 & 0.113 \\
\hline Plant growth type (\#) & -0.278 & 0.091 & 0.066 & 0.137 & 0.035 \\
\hline Fruit size $\left(\mathrm{cm}^{3}\right)$ & 0.270 & -0.017 & 0.035 & 0.308 & 0.058 \\
\hline
\end{tabular}

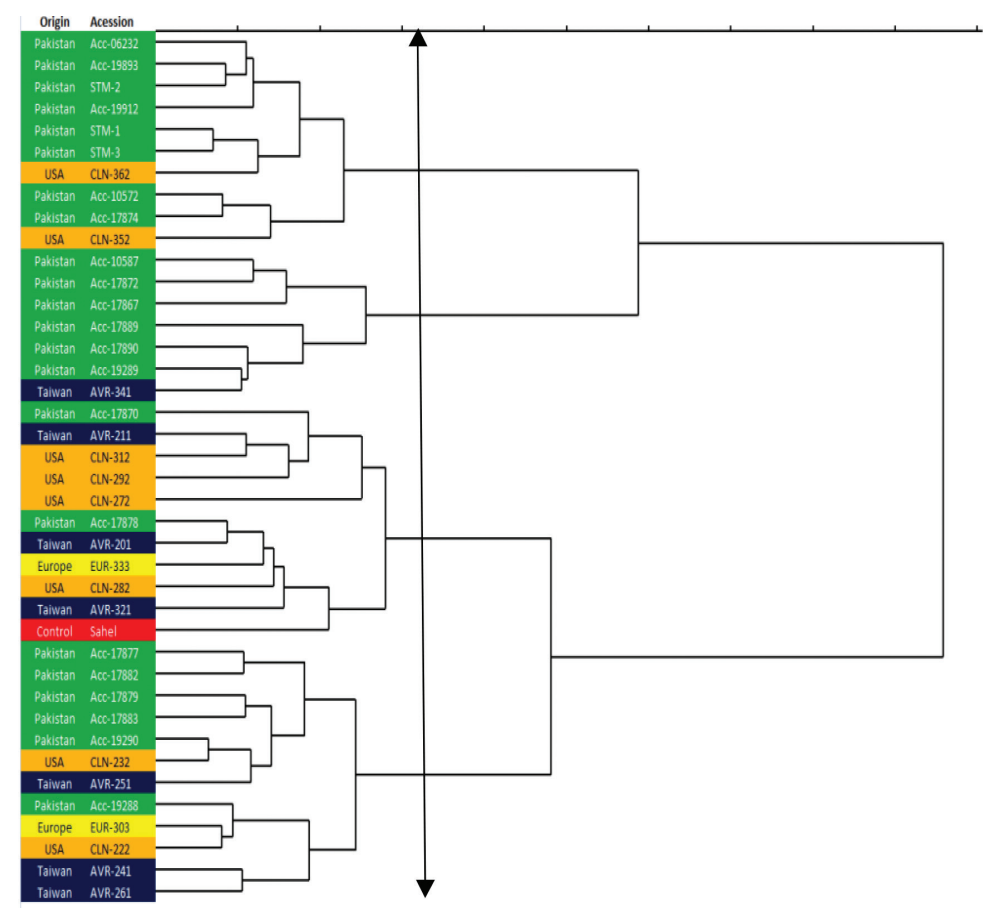

FIGURE 3. Dendrogram showing the genetic diversity within 40 tomato accessions through agro-morphological traits 
TABLE 3. Grouping of 40 tomato accessions based on agro-morphological traits through cluster analysis

\begin{tabular}{cclc}
\hline Cluster & Sub-Cluster & Accessions & No. of accessions \\
\hline I & IA & Acc-19288, EUR-303, CLN-222, & 5 \\
& AVR-241, AVR-261 & 7 \\
IB & Acc-17877, Acc-17882, Acc-17879, & \\
& Acc-17883, Acc-19290, CLN-232 & 6 \\
II & AVR-251 & 5 \\
& IIA & Acc-17878, AVR-201, EUR-333, & 5 \\
& CLN-282, AVR-321, Sahel & 4 \\
III & Acc-17870, AVR-211, CLN-312, & CLN-292, CLN-272 \\
& IIIA & Acc-17889, Acc-17890, Acc-19289, & 3 \\
& AVR-341 & Acc-10587, Acc-17872, Acc-17867 \\
IIIB & Acc-10572, Acc-17874, CLN-352 & 3 \\
& IVA & Acc-06232, Acc-19890, STM-2, & 7 \\
& Acc-19912, STM-1, STM-3, & CLN-362 \\
& & &
\end{tabular}

TABLE 4. Means and standard deviations (SD) of four clusters based on agro-morphological traits

\begin{tabular}{|c|c|c|c|c|}
\hline Traits & $\begin{array}{l}\text { Cluster-I } \\
\text { (12) }\end{array}$ & $\begin{array}{c}\text { Cluster-II } \\
\text { (11) }\end{array}$ & $\begin{array}{c}\text { Cluster-III } \\
\text { (7) }\end{array}$ & $\begin{array}{c}\text { Cluster-IV } \\
\text { (10) }\end{array}$ \\
\hline Days to germination (\#) & $8 \pm 0.8$ & $8 \pm 1.0$ & $7 \pm 0.7$ & $7 \pm 1.4$ \\
\hline Days to flowering (\#) & $49 \pm 2.9$ & $88 \pm 3.7$ & $44 \pm 2.2$ & $49 \pm 1.9$ \\
\hline Days to fruiting (\#) & $19.2 \pm 1.9$ & $18.4 \pm 3.1$ & $15.6 \pm 1.3$ & $19.1 \pm 1.4$ \\
\hline Clusters plant ${ }^{-1}(\#)$ & $7.3 \pm 1.7$ & $6.9 \pm 2.6$ & $21.9 \pm 3.0$ & $12 \pm 2.4$ \\
\hline Flowers cluster ${ }^{-1}$ (\#) & $6.8 \pm 1.0$ & $6.6 \pm 1.3$ & $11.3 \pm 1.5$ & $8.8 \pm 0.9$ \\
\hline Fruits cluster-1 $\left.^{-1} \#\right)$ & $5.8 \pm 0.7$ & $5.5 \pm 1.1$ & $9.4 \pm 1.0$ & $7.5 \pm 0.8$ \\
\hline Fruits plant ${ }^{-1}(\#)$ & $40.5 \pm 14.3$ & $38.5 \pm 22.4$ & $197.3 \pm 43.7$ & $46.7 \pm 20.8$ \\
\hline Fruits weight plant ${ }^{-1}(\mathrm{~kg})$ & $1.2 \pm 0.2$ & $1.2 \pm 0.4$ & $1.1 \pm 0.1$ & $1.1 \pm 0.1$ \\
\hline Yield plot ${ }^{-1}(\mathrm{~kg})$ & $4.7 \pm 0.8$ & $4.7 \pm 1.3$ & $4.4 \pm 0.5$ & $4.3 \pm 0.6$ \\
\hline Yield hectare $^{-1}$ (tonnes) & $28.321 \pm 4.693$ & $28.282 \pm 7.603$ & $26.490 \pm 2.982$ & $25.657 \pm 3.332$ \\
\hline Fruit diameter $(\mathrm{cm})$ & $5.4 \pm 1.1$ & $5.5 \pm 1.4$ & $3 \pm 0.6$ & $3.2 \pm 0.5$ \\
\hline Fruit width $(\mathrm{cm})$ & $5.4 \pm 1.1$ & $5.4 \pm 1.3$ & $3.1 \pm 0.6$ & $3.2 \pm 0.5$ \\
\hline Fruit length $(\mathrm{cm})$ & $4.8 \pm 1.1$ & $5.9 \pm 0.8$ & $3.2 \pm 0.6$ & $3.2 \pm 0.5$ \\
\hline Plant height (cm) & $76.1 \pm 3.8$ & $73.7 \pm 6.4$ & $114.5 \pm 13.3$ & $84.8 \pm 4.8$ \\
\hline Plant stem girth $(\mathrm{cm})$ & $4.9 \pm 0.6$ & $4.9 \pm 0.7$ & $4.5 \pm 0.2$ & $4.7 \pm 0.4$ \\
\hline Plant stem diameter $(\mathrm{cm})$ & $1.6 \pm 0.2$ & $1.6 \pm 0.2$ & $1.4 \pm 0.1$ & $1.5 \pm 0.1$ \\
\hline Leaf length $(\mathrm{cm})$ & $24.4 \pm 3.1$ & $27.6 \pm 2.9$ & $25.5 \pm 2.9$ & $23.1 \pm 3.3$ \\
\hline Leaf width $(\mathrm{cm})$ & $18.9 \pm 3.1$ & $19.8 \pm 1.9$ & $17.3 \pm 2.6$ & $17.3 \pm 1.7$ \\
\hline Fruit size $\left(\mathrm{cm}^{3}\right)$ & $5.4 \pm 1.1$ & $5.4 \pm 1.3$ & $3.1 \pm 0.6$ & $3.2 \pm 0.5$ \\
\hline
\end{tabular}

FPC exhibited positive significant association with FPP, but negative significant effects were observed with FW, FL, FWidth and FS. Significantly negative correlation of FPP with FL, FWidth and FS was observed, whereas FW manifested highly significant positive association with FL and YPH and significantly positive correlation with FWidth and FS. Similarly, FL showed high significant positive association with FWidth, FS and YPH. Moreover, FWidth was also highly significant correlated with FS (Table 6).

\section{DISCUSSION}

Forty accessions of tomato evaluated through PCA were grouped into different clusters with more morphological similarities among accessions within cluster. The distribution of tomato accessions into different groups revealed that the genetic diversity existed among these accessions. The scattered plot of the PC showed that the accessions were scattered in all the quarters, which is also a representative that high level of genetic variability 
TABLE 5. Salient features of four clusters of tomato accessions

\begin{tabular}{|c|c|}
\hline Clusters & Salient Features \\
\hline $\mathrm{I}$ & $\begin{array}{l}\text { Average in days to germination, average in days to } 50 \% \text { flowering, maximum in days to fruiting, average clusters } \\
\text { plant }^{-1} \text {, average flowers cluster }{ }^{-1} \text {, average fruits cluster }{ }^{-1} \text {, average fruits } \text { plant }^{-1} \text {, above average fruit weight plant }{ }^{-1} \text {, } \\
\text { above average yield } \text { plot }^{-1} \text {, maximum yield hectare }{ }^{-1} \text {, above average fruit diameter, above average fruit width, above } \\
\text { average fruit length, average plant height, above average plant stem girth, maximum plant stem diameter, average in } \\
\text { leaf length, above average leaf width, maximum fruit size }\end{array}$ \\
\hline II & $\begin{array}{l}\text { Average in days to germination, maximum in days to } 50 \% \text { flowering, average in days to fruiting, minimum clusters } \\
\text { plant } t^{-1} \text {, minimum flowers cluster }{ }^{-1} \text {, minimum fruits } \text { cluster }^{-1} \text {, minimum fruits plant }{ }^{-1} \text {, above average fruits weight plant }{ }^{-1} \text {, } \\
\text { maximum in yield plot }{ }^{-1} \text {, above average in yield hectare }{ }^{-1}, \text { maximum fruit diameter, maximum fruit width, maximum } \\
\text { fruit length, minimum plant height, maximum plant stem girth, maximum plant stem diameter, maximum leaf length, } \\
\text { maximum in leaf width, maximum fruit size }\end{array}$ \\
\hline III & $\begin{array}{l}\text { Early in germination, minimum in flowering, minimum in fruiting, maximum clusters plant }{ }^{-1} \text {, maximum flowers cluster }{ }^{-1} \text {, } \\
\text { maximum fruits cluster }{ }^{-1} \text {, maximum fruits plant }{ }^{-1} \text {, average in fruits weight } \text { plant }^{-1} \text {, average yield plot }{ }^{-1} \text {, average yield } \\
\text { hectare }{ }^{-1} \text {, minimum fruit diameter, minimum fruit width, average fruit length, maximum plant height, minimum plant } \\
\text { stem girth, minimum plant stem diameter, above average in leaf length, average in leaf width, minimum fruit size }\end{array}$ \\
\hline IV & $\begin{array}{l}\text { Early in germination, average in flowering, early in fruiting, above average clusters plants }{ }^{-1} \text {, above average flowers } \\
\text { cluster }{ }^{-1} \text {, above average fruits cluster }{ }^{-1} \text {, above average fruits plant }{ }^{-1} \text {, average in fruits weight } \text { plant }^{-1} \text {, minimum yield plot }{ }^{-1} \text {, } \\
\text { minimum yield hectare }{ }^{-1} \text {, average fruit diameter, average fruit width, minimum fruit length, above average plant height, } \\
\text { average plant stem girth, average plant stem diameter, minimum leaf length, minimum leaf width, average fruit size }\end{array}$ \\
\hline
\end{tabular}

TABLE 6. Estimated association between yield and yield related traits of tomato accessions of diverse origin, evaluated at the agro-climatic conditions of Haripur and Swabi

\begin{tabular}{|c|c|c|c|c|c|c|}
\hline Traits & Fr PC & Fr PP & Fr Weight & Fr Length & Fr Width & Fr Size \\
\hline Fr PP & $0.86^{* *}$ & & & & & \\
\hline Fr Weight & $-0.16^{*}$ & -0.04 & & & & \\
\hline Fr Length & $-0.61^{*}$ & $-0.53^{* *}$ & $0.29^{* *}$ & & & \\
\hline Fr Width & $-0.63^{* * *}$ & $-0.60^{* *}$ & $0.16^{*}$ & $0.29^{* * *}$ & & \\
\hline Fr Size & $-0.63^{* *}$ & $-0.60^{* *}$ & $0.16^{*}$ & $0.82^{* *}$ & $0.99^{* *}$ & \\
\hline YPH & -0.07 & 0.04 & $0.95^{* *}$ & $0.23^{* *}$ & 0.11 & 0.10 \\
\hline
\end{tabular}

is present among the evaluated accessions, providing a resource for the development of improved varieties in future breeding program. The results of the present study revealed that grouping was not associated with geographic origin because some genotypes collected from the same geographic origin were grouped in different clusters. The findings of the present investigation are supported by the findings of Chernet et al. (2014), who observed six principle components PC1, PC2, PC3, PC4, PC5 and PC6 with eigenvalues $8.915,3.309,3.104,2.012,1.430$ and 1.330 , respectively, accounted for $83.03 \%$ of the total variation. The first two principle components PC1 and PC2 with a proportion of $37.14 \%$ and $13.79 \%$, respectively, contributed more to the total variation. In further support to our findings, Iqbal et al. (2014) reported that the contribution of PC1 towards variability was the highest (44.20\%), followed by PC2 and PC3 which contributed $22.97 \%$ and $14.55 \%$ variability, respectively. The traits which have major contribution in the total variation were DFL, DFR, FS, FW, YPP, YPH, LL, PDFS, FL, F Width, CPP, FRPC and $\mathrm{PH}$ which are in agreement with the findings of Bhattarai et al. (2016), Cebolla-Cornejo et al . (2013), Hu et al. (2012), Mazzucato et al. (2008) and Zhou et al. (2015) who characterized tomato genotypes in different regions round the globe, using molecular and phenotypic traits.

The findings of the cluster analysis through agromorphological traits of tomato are in agreement with the results of Henareh et al. (2015). They obtained significant results of genetic variability among the studied agromorphological traits for tomato accessions through the two complementary techniques (PCA and cluster analysis). The accessions in cluster I showed similarities with maximum number of DFR, maximum FW, maximum YPH, whereas in cluster II accessions were found similar on the basis of maximum values for yield and yield related traits, which may be combined with desirable quality traits in future breeding program for good variety or hybrid development. However, accessions grouped in clusters III and IV were associated with minimum values for growth and growth related traits and yield. PCA and clustering techniques were found fruitful in tomato by Iqbal et al. (2014), who also found similar grouping results on the basis of similarities among genotypes, which give support to the present study. They reported that cluster analysis can be regarded as an efficient tool to categorize germplasm and render reliable basis in choice of base material to plan future breeding 
strategies. They also showed that multivariate analysis helps to place the genotypes in different clusters on the basis of PC(s) values. Cluster analysis was also found significant in tomato by Chernet et al. (2014).

The findings of De-Souza et al. (2012) agreed for correlation of FPC with FPP, but contrasting results were obtained for FPC with FL. Reddy et al. (2013) obtained nonsignificant positive association of FPC with FPP, which is not in line with our results. Iqbal et al. (2014) also showed that FPP was in significant negative association with FWidth, which reflected that the increase in FPP resulted the decrease in FWidth. Highly significant positive association in tomato was observed for yield with FW, FL and FWidth (Nwosu et al. 2014). Reddy et al. (2013) also found positive significant correlation of FWidth with FW which is in accordance with our results. This association shows that the increase in FWidth leads to the increase in FW as well. Bernousi et al. (2011) recorded positive significant correlation for FW with FWidth and FL which is in harmony with our results. Islam et al. (2010) also estimated positive significant correlation of fruit diameter/width both at genotypic and phenotypic levels with individual FW and yield plant ${ }^{-1}$ which indicated that as the diameter of fruits increases the individual FW and yield plant ${ }^{-1}$ would increase.

A very high and significant correlation coefficient between yield and FW was observed (Harer et al. 2002; Mohanthy 2002a, 2002b; Prasad \& Rai 1999). The results were in accordance with Dhankhar and Dhankar (2006) for FPP, Kumar et al. (2006), Singh $(2009,2007)$ for FWidth and Reddy et al. (2013) for both FPP and FWidth. De-Souza et al. (2012) and Haydar et al. (2007) observed positive correlation between fruit yield and the FPP, whereas Basavaraj and Dhotre (2012) found very strong correlation between yield and FPP, and they suggested in order to obtain high yielding genotypes, selection should be done for high FPP and more number of branches per plant.

\section{CONCLUSION}

Grouping of tomato accessions into different clusters were associated with agro-morphological difference instead of geographic circulation. The major contribution in total variation was observed in phenological, physiological and yield components. Accessions in clusters I and II were found promising for economically important traits and are of potential as a source for further improvement and selection breeding programs in tomato.

\section{ACKNOWLEDGEMENTS}

I feel pleasure to thank my supervisory committee and University of Haripur for their, cooperation, guidance and valuable suggestions which enabled me to write my thesis and publication.

\section{REFERENCES}

Basavaraj, N. \& Dhotre, M. 2012. Correlation and path coefficient studies in tomato. Asian J. Hortic. 7(2): 379-384.
Bernousi, I., Emami, A., Tajbakhsh, M., Darvishzadeh, R. \& Henareh, M. 2011. Studies on genetic variability and correlation among the different traits in Solanum lycopersicum L. Not. Bot. Hort. Agrobot. Cluj. 39(1): 152-158.

Bhattarai, K., Louws, F.J., Williamson, J.D. \& Panthee, D.R. 2016. Diversity analysis of tomato genotypes based on morphological traits with commercial breeding significance for fresh market production in eastern USA. Austr. J. Crop Sci. 10(8): 1098-1103.

Cebolla-Cornejo, J., Rosello, S. \& Nuez, F. 2013. Phenotypic and genetic diversity of Spanish tomato landraces. Scientia Hortic. 162: 150-164.

Chernet, S., Belew, D. \& Abay, F. 2014. Genetic diversity studies for quantitative traits of tomato (Solanum lycopersicon L.) genotypes in Western Tigray, Northern Ethiopia. J. Plant Breed. Crop Sci. 6(9): 105-113.

Crossa, J. \& Franco, D.J. 2004. Statistical methods for classifying genotypes. Euphytica 137: 19-37.

De-Souza, L.M., Melo, P.C.T., Luders, R.R. \& Melo, A.M. 2012. Correlations between yield and fruit quality characteristics of fresh market tomatoes. Hortic. Bras. 30(4): 627-631.

Dhankhar, S.K. \& Dhankhar, B.S. 2006. Variability, heritability, correlation and path-coefficient studies in tomato. Haryana J. Hortic. Sci. 35(1/2): 179.

FAOSTAT. 2015. Statistical Databases. Food and Agriculture Organization. Accessed by 10 April 2017 at http://faostat3. fao.org/home/E.

Flint-Garcia, S.A., Thuillet, A.C., Yu, J.M., Pressoir, G., Romero, S.M., Mitchell, S.E., Doebley, J., Kresovich, S., Goodman, M.M. \& Buckler, E.S. 2005. Maize association population: A high-resolution platform for quantitative trait locus dissection. Plant J. 44(6): 1054-1064.

Hanson, P., Chen, J.T., Kuo, C.G., Morris, R. \& Opena, R.T. 2000. Suggested cultural practices for tomato. Int. Coop. Guide AVRDC \#00-508. pp. 1-8.

Harer, P.N., Lad, D.B. \& Bhor, T.J. 2002. Correlation and path analysis studies in tomato. J. Maharashtra Agric. Uni. 27(3): 302-303.

Haydar, A., Mandal, M.A., Ahmed, M.B., Hannan, M.M., Karim, R., Razvy, M.A., Roy, U.K. \& Salahin, M. 2007. Studies on genetic variability and interrelationship among the different traits in tomato (Lycopersicon esculentum Mill.). Middle-East J.Sci.Res. 2(3-4): 139-142.

Henareh, M., Dursun, A. \& Mandoulakani, B.A. 2015. Genetic diversity in tomato landraces collected from Turkey and Iran revealed by morphological characters. Acta. Sci.PolonorumHortorum Cultus 14: 87-96.

Hu, X.R., Wang, H., Chen, J. \& Yang, W.C. 2012. Genetic diversity of Argentina tomato varieties revealed by morphological traits, simple sequence repeat, and single nucleotide polymorphism markers. Pak.J.Bot.44: 485-492.

Huang, X.H., Zhao, Y., Wei, X.H., Li, C.Y., Wang, A., Zhao, Q., Li, W.J., Guo, Y.L., Deng, L.W., Zhu, C.R., Fan, D.L., Lu, Y.Q., Weng, Q.J., Liu, K.Y., Zhou, T.Y., Jing, Y.F., Si, L.Z., Dong, G.J., Huang, T., Lu, T.T., Feng, Q., Qian, Q., Li, J.Y. \& Han, B. 2012. Genome-wide association study of flowering time and grain yield traits in a worldwide collection of rice germplasm. Nat. Genet. 44(1): 32-53.

Huang, X., Wei, X., Sang, T., Zhao, Q., Feng, Q., Zhao, Y., Li, C., Zhu, C., Lu, T., Zhang, Z., Li, M., Fan, D., Guo, Y., Wang, A., Wang, L., Deng, L., Li, W., Lu, Y., Weng, Q., Liu, K., Huang, T., Zhou, T., Jing, Y., Li, W., Lin, Z., Buckler, E.S., Qian, Q., Zhang, Q.F., Li, J. \& Han, B. 2010. Genome-wide 
association studies of 14 agronomic traits in rice landraces. Nat. Genet. 42(11): 961-976.

Iqbal, Q., Saleem, M.Y., Hameed, A. \& Asghar, M. 2014. Assessment of genetic divergence in tomato through agglomerative hierarchical clustering and principal component analysis. Pak. J. Bot. 46(5): 1865-1870.

Islam, B.M.R., Ivy, N.A., Rasul, M.G. \& Zakaria, M. 2010. Character association and path analysis of exotic tomato (Solanum lycopersicum L.) genotypes. Bangl.J.Plant Breed. Genet. 23(1): 13-18.

Jackson, J. 1991. A User's Guide to Principal Components. New York: John Wiley \& Sons.

Khadivi-Khub, A., Zamani, Z. \& Bouzari, N. 2008. Evaluation of genetic diversity in some Iranian and foreign sweet cherry cultivars by using RAPD molecular markers and morphological traits. Hortic. Environ. Biotechnol. 49: 188196.

Kumar, R., Mishra, N.K., Singh, J., Rai, G.K., Verma, A. \& Rai, M. 2006. Studies on yield and quality traits in tomato (Solanum lycopersicon Mill.). Veg. Sci. 33(2): 126-132.

Mazzucato, A., Papa, R., Bitocchi, E., Mosconi, P., Nanni, L., Negri, V., Picarella, M.E., Siligato, F., Soressi, G.P., Tiranti, B. \& Veronesi, F. 2008. Genetic diversity, structure and markertrait association in a collection of Italian tomato (Solanum lycopersicum L.) landraces. Theor. Appl. Genet. 116: 657-669.

MNFSR. 2014-2015. Fruits, Vegetables and Condiments Statistics of Pakistan. Government of Pakistan, Ministry of National Food Security and Research. p. 69.

Mohammadi, S.A. \& Prasanna, B.M. 2003. Analysis of genetic diversity in crop plants - salient statistical tools and considerations. Crop Sci.43: 1235-1248.

Mohanty, B.K. 2002a. Studies on variability, heritability, interrelationship and path analysis in tomato. Anl. Agric. Res. 2(1): 65-69.

Mohanty, B.K. 2002b. Genetic variability, correlation and path coefficient studies in tomato. Ind. J.Agric.Res, 37(1): 68-71.

Nikoumanesh, K., Ebadi, A., Zeinalabedini, M. \& Gogorcena, Y. 2011. Morphological and molecular variability in some Iranian almond genotypes and related Prunus species and their potentials for rootstock breeding. Sci. Hortic. 129: 108-118.

Nwosu, D.J., Onakoya, O.A., Okere, A.U., Babatunde, A.O. \& Popoola, A.F. 2014. Genetic variability and correlations in rainfed tomato (Solanum spp.) accessions in Ibadan, Nigeria. Greener J. Agric. Sci. 4(5): 211-219.

Prasad, V.S.R.K. \& Rai, M. 1999. Genetic variation, component association and direct and indirect selections in some exotic tomato accessions. Ind. J. Hortic. 56(3): 262-266.

Rashid, M., Cheema,A.A.\& Ashraf, M. 2008. Numerical analysis of variation among basmati rice mutants. Pak.J. Bot. 40(6): 2413-2417.

Reddy, B.R., Reddy, M.P., Begum, H. \& Sunil, N. 2013. Genetic diversity studies in tomato (Solanum lycopersicum L.). IOSR J. Agric. Veterinary Sci. 4(4): 53-55.

Reif, J.C., Melchinger, A.E. \& Frisch, M. 2005. Genetical and mathematical properties of similarity and dissimilarity coefficients applied in plant breeding and seed bank management. Crop Sci.45: 1-7.
Singh, A.K. 2009. Genetic variability, heritability and genetic advance studies in tomato under cold arid region of Ladakh. Ind. J. Hortic. 66(3): 400-403.

Singh, A.K. 2007. Correlation and path coefficient studies in tomato under cold arid conditions of Ladakh. Haryana $J$ Hortic. Sci. 36(3/4): 346-347.

Sneath, P.H. \& Sokal, R.R. 1973. Numerical Taxonomy: The Principles and Practice of Numerical Classification. San Francisco, USA: W.F. Freeman \& Co.

Steel, R.G.D. \& Torrie, J.H. 1980. Principles and Procedures of Statistics. 2nd ed. New York: McGraw-Hill.

Sudre, C.P., Leonardecz, E., Rodrigues, R., Junior, A.T.D.A., Moura, M.D.C.L. \& Gonçalves, L.S.A. 2007. Genetic resources of vegetable crops: A survey in the Brazilian germplasm collections pictured through papers published in the journals of the Brazilian Society for Horticultural Science. Hortic. Bras. 25: 496-503.

Terzopoulos, P.J. \& Bebeli, P.J. 2008. DNA and morphological diversity of selected Greek tomato (Solanum lycopersicum L.) landraces. Sci. Hortic. 116: 354-361.

Thornsberry, J.M., Goodman, M.M., Doebley, J., Kresovich, S., Nielsen, D. \& Buckler, E.S. 2001. Dwarf8 polymorphisms associate with variation in flowering time. Nat. Genet. 28(3): 286-289.

Yi, S-S., Jatoi, S.A., Fujimura, T., Yamanaka, S., Watanabe, J. \& Watanabe, K.N. 2008. Potential loss of unique genetic diversity in tomato landraces by genetic colonization of modern cultivars at a non-center of origin. Plant Breed. 127: 189-196.

Zhou, R., Wu, Z., Cao, X. \& Jiang, F.L. 2015. Genetic diversity of cultivated and wild tomatoes revealed by morphological traits and SSR markers. Genet. Mol. Res. 14: 13868-13879.

Izhar Hussain 1*, Sher Aslam Khan, Abid Farid, Naushad Ali, Sardar Ali, Shah Masaud, Ijaz Hussain \& Kamran Azeem Department of Agricultural Sciences

University of Haripur, 22620

Pakistan

Sajid Ali

Institute of Biotechnology and Genetic Engineering

University of Agriculture Peshawar, KPK

Pakistan

\section{Haneef Raza}

Department of plant breeding and Genetic

University of Agriculture Peshawar, KPK

Pakistan

*Corresponding author; email: izharhussain29@gmail.com

Received: 19 December 2017

Accepted: 28 June 2018 